Kom, 2019, vol. VIII (3) : 81-97

UDC: $72.01: 28$

726.2

DOI: $10.5937 /$ kom $1903081 \mathrm{R}$

Original scientific paper

\title{
A Study of Islamic Leaders' Strategic Role IN ISLAMIC ARCHITECTURES
}

Hamid Reza Shojaifard

University of Religion and Denominations, Qom, I. R. Iran

\section{Zahra Sajadi}

University of Religion and Denominations, Qom, I. R. Iran

\begin{abstract}
The architecture issue is one of the important factors in the Islamic civilization that Muslims have considered a lot in religious leaders' teachings. The applied purposes of this article are based on the religious Imams' statements including scientific and practical approaches to the Islamic architectural harmonization, urban structures and elimination of factors that destroy urban civilizations. Religious leaders have commented on Islamic architecture leading to civilized societies. These comments include urbanization, making green spaces, building structures facing Qibla, building horizontal-oriented houses and avoiding some special manifestations in architecture such as statues. As one of the dimensions of art is architecture, Muslims have paid attention to the construction of mosques and monasteries, which are quite present in Islamic architecture. It is a descriptive and analytical article; and it refers to architectural modeling features that religious leaders have introduced in their speeches.
\end{abstract}

Keywords: Islamic architecture, Islamic civilization, Islam, religious leaders (Imams), urbanization

\section{Introduction}

Religious doctrines have a very important role in consolidating the foundations and expansion of Islamic civilization. Some verses in the Holy Quran

Corresponding author: shojaeifard@gmail.com

Corresponding author: zahra.sajady1@gmail.com 
point out architecture, urbanization, housing, beautification and architectural strengthening both generally and specifically (see: Quran 16: 80-81, 112; 57: 82; 26: 49; 14: 35; 28: 57). General architectural principles of urban life and urbanization were based on theological criteria by executing the Quran commands in the field of architecture and urbanization. Religious leaders (Imams), who were executors of these commands in the Quran, could provide promotional items of Islamic civilization.

In the survey, we study characteristics and principles of Islamic architecture from the viewpoint of religious leaders. In this case, this survey can answer the following questions:

1. What are the characteristics of the principles of Islamic architecture in terms of religious leaders?

2. How can religious leaders' views help modern architecture in the field of Islamic architecture?

3. What impact can religious leaders' comments in Islamic architecture have on urban constructions?

\section{Methodology}

It is a descriptive-analytic study based on library documents. In order to analyze this subject, we refer to the Quran and infallible Imams' traditions and comments. Moreover, we use new sources of research and architecture.

\section{A. Mosques, Infrastructures and the Beginning of Islamic Architecture}

According to what has been written in the books of history, Prophet $\mathrm{Mu}$ hamad went to Medina on Monday on $12^{\text {th }}$ of Rabi'at al-Ula (fourteenth year of Bithah / about 622 in Gregorian Calendar), and when he arrived there, he built a mosque named "Quba". Having stayed in the mosque for four days, Prophet Muhammad went to Medina on Friday (four days later). Many Ansars (disciples from Medina) went there to give a warm welcome to the Prophet. The warm welcome got the Prophet to leave the camel, and then he said: "Let it go, because he is an agent". At the time of his prayers, he arrived at the place of the Bani Salam's tribe (see: Masoudi 1989: II/279). After that, he rode on a camel and moved toward "the Medina Mosque" continuously. The camel stopped at a land, and then the prophet asked the landowner a question. The owner said: "This land belongs to two orphans from the Banu 
Najjar tribe" (Ibn Juzi 1992: 3, 65). The prophet bought this land and he built the "al-Nabi Mosque".

He stayed in Abu Ayoob Ansari's house until the mosque and his house were built (al-Miqrizi 1999: X/69). This was the beginning of the dynamical movement of Islamic architecture in Medina. We will talk about it in this survey: the indicators and principles of Islamic architecture of the mosque from the religious leaders' viewpoint. They have stated some principles for Islamic architecture of mosques by which correct Islamic architectural features could be realized.

These principles are as follows.

\section{Centralizing of the Mosque Location}

Studying religious and historical texts on the location of the "Masjid al-Nabi", we can find out that the location of the mosque played an important role in architecture of the first mosque in those days. It was important because the Muslims' architectural infrastructure was carried out at the center of the city in Medina by the establishment of the mosque. Apart from being the place of worshipping God, the Masjid al-Nabi was where Muslims conducted political, economic, social, cultural and military issues of society on the basis of Islamic principles. The Islamic community must consider this issue today, that is, mosques ought to be built in central places of living. In this way, Muslims can provide promotion of religious rituals and Islamic propaganda. In fact, we should pay attention to the fact that centralizing Muslims' mosques in city (city centers) must be reserved and respected. This center is not necessarily a geometric center; however, it does not have a contradiction. Architects must locate and build mosques in city centers. In that way, Muslims can have access to important issues and events in a consistent and regular hierarchy, even with unwritten Islamic criteria (the reported issues can meet their different needs) (Ibn Hisham 1991: 489; Naqizadeh 2008: 356).

\section{Simplicity of the Mosque Building}

One of the teachings we learn from religious leaders about building the mosque is simplicity. The mosque reminds us to forget everything except Him (God), therefore we must avoid making enything that leads us to non-godliness in the mosque (Jawadi Amuli 2014: 565). Imam Ja'far ibn Muhammad as-Sadiq talked about the approach and reflection of the mosque's simplicity in the construction of the Prophet Mosque, and he said: "The Prophet built his mosque with bricks". As the population of Muslims grew, 
they asked the Prophet to develop the mosque. Prophet agreed with them, and then the mosque was developed and built with clay. The heat of the sun bothered the Muslims (in Arabia). Muslims asked the prophet to let them make a sunshade for the mosque. The prophet also agreed with them. They erected some palm trees in the middle of the mosque. The trees were full of branches, leaves and cucurbits (a fragrant plant). When it was rainy, the raindrops fell from the ceiling of the mosque. Muslims asked the prophet to let them cover the roof of the mosque with clay. It could prevent the raindrops from falling inside.

The Prophet disagreed with them and said: "The ceiling of the mosque should be tiled as Moses' synagogue”. During Muhammad's prophecy, the construction of the mosque was the same until the prophet of Islam died. The mosque wall was as high as a person's height (Yaqubi n. d.: 42). About the simplicity of the mosque the Prophet said: "Make your mosques simple and without battlements (i.e. a mosque must be simple and should not disturb the neighbors.) Make your cities look beautiful; they should be eye-catching and they should have views" (Suyuti 1981: 13; Muttaqi Hindi 1989: 769; Jawadi Amuli 2014: 565). He also said: "Do not decorate your mosques with jewelry, contrary to Jews and Christians who decorate their synagogues and churches" (Fayz Kashani n. d.: VI/346; Nuri 1988: III/371). He also said: "As the group acts badly, they can adorn their mosques" (Ibn Majah n. d.: I/245). Such reports of religious leaders also attracted some insurrections. A Christian Priest wrote in his book The History of Islamic Art: "During the reign of Mohammad, the first mosques in Arabia were rectangular; one side of it was roofed to avoid wind and rain. There were neither altars nor statues of the pious people. There were neither gold and silver pots nor hung ornamentals on walls. It was forbidden to put statues and images of living things in mosques. While Prophet Muhammad called for people in Mecca to Islam, he broke the idols of unbelievers there. God is the only one who knows how to create humans and animals. While Christians draw and paint Jesus Christ's face, Muslims cannot imagine a picture of God. The mosque was as simple as their buildings" (Priest 1985: 13).

\section{Minarets of Mosques}

As it is written and recorded in history books, mosques had no minarets during the Prophet's time. It has also been narrated that as Amir alMu'minin Ali ibn Abi Talib passed by a high minaret, he commanded that the minaret should be pulled down. Then he said: "We should not build a high minaret except on the roof of the mosque" (Saduq 1994: I/ 239; Tusi 1987: III/256). 


\section{Construction of the}

Central Courtyard for the Mosque

The only architectural forms that were built as the Prophet's Mosque, and then it was agreed to build the main dual space of the mosque, were the indoor and the outdoor as the courtyard. Minarets, lecterns, domes and so on, were added to the mosque's architecture later. At the time of Muhammad, these things were not needed, and therefore Muslims did not make them. Due to Islam conquering new large cities, and Muslims' population increasing in different regions, Muslims in modern world built a special architecture for Azan (Prayer Call).

For centuries, the courtyard or open space of the mosque was one of the most important elements built in mosques in Islamic countries either by Caliphs and Sultans or ordinary people. They have both been the mosque's identity and the manifestation of their unity. People in the Middle East have used the central courtyard in architecture for many years. However, there were three factors leading Muslims to use the central courtyard as one of the main elements in the construction of mosques.

They are as follows:

1. Influence of the worldview of Islam;

2. The pattern of the mosque in Medina;

3. Traditions.

The Medina mosque was in the open space, and the prophet liked to have the mosque simple; he would not add anything to the mosque if it weren't necessary. The central courtyard of the mosques played an important role for people and social communities in holding Friday prayers, Aid al-Fitr prayers and Aid al-Adha. The big open-space courtyard of the mosque can make a meaningful concept for mosques. This meaningful space attracts people, and it let prayers get ready to say their prayers. Mosques as high-spiritual places are comprehensive and important. Therefore, they are the main determinants of the Islamic society, and besides, mosques can lead to unity of Muslims in all areas such as cities and villages.

This identification is not only in terms of form and image but also of other measures such as functionality, centrality and location of establishment. Mosques were the first and most significant elements of Muslim cities that could attract newcomers (Naqizadeh 2008: 161). 


\section{Avoiding Construction of the Battlements for the Mosque}

Based on Sheikh Saduq's citation in an authentic narrative, it is said: "Amir al-Mu'minin Ali ibn Abi Talib saw a mosque with battlements in Kufa. He said: 'It is like Jewish holy places and mosques. Mosques must not have battlements. The wall should be simple and even."'

Abū Basir also quoted a long narrative by Imam Muhammad Baqir: "When Imam al-Qaim (Mahdi) will rebel, and he will go to Kufa and destroy four mosques there, mosques with battlements will be no more on earth. Imam will wreck and eradicate all mosques" (Fattal Nishaburi 1996: II/264).

It emphasizes that mosques must have no battlements. On the one hand, it is a sign that Islam is a complete religion and Muslims must not get or use any architectural patterns by other religions, and on the other hand, battlements are a sign of luxury and they are away from the philosophy of simplicity. They can increase the attentiveness of worldliness and stop Muslims from paying attention to the next world.

\section{The Altar of the Mosque}

Making altar in a common way, which is only a small architectural effect on the mosque wall or a small amount of chamfering in the wall to determine the Qibla, was not a problem. The thing which is considered in jurists' books as one of the problems of the mosque's building, is the building of the "altar inside" (see: Tusi 2008: I/160; Karaki 1993: II/145; Najafi n. d.: XIV/109). Sheikh Sadukh says about the destruction of altars in mosques: "Amir al-Mu'minin Ali ibn Abi Talib destroyed the altar of mosques wherever he saw them. He said: 'They are like Jewish abattoirs'” (Saduq 2006: 320).

Some jurists such as Muhammad ibn Ahmad Amili and Zayn ad-Din al-Jubai al-Amili explained the word "breaking the altar" in this narrative: "He believed the altar in this narrative is the altar that was built elsewhere, and outside the mosque wall" (Amili 1998: III/123; al-Jubai Amili n. d. 236).

Some other jurisprudents believe that the narrative is intended to deny the graffiti made by Caliphs in mosques.

\section{The Lack of High Altitude of the Mosque}

Studying narratives in the traditions of religious leaders, we can conclude that mosques should not overlook buildings in the neighborhood. This is a kind of adaptation of architectural patterns by Jews and Christians; however, Islam forbids it. 
Sheikh Saduq in 'Ilal al-Sharayi' writes: "Imam Ali ibn Abi Talib saw a mosque in Kufa, overlooking the surrounding buildings, and said: 'It seems this temple is for Judaists and Christians, mosques must not be high, and they must be short"' (Saduq 2006: II/320).

\section{The Destruction of Mosques along the Roads}

In one of his books Sheikh Mufid narrated a statement from Abū Basir: "Imam Muhammad Baqir once said:'If Imam Mehdi protests, he will destroy all mosques. He will do it because these mosques are in the way because of the crowd's noise. It can disturb people. Moreover, other people, non-Muslims, may meddle in the mosque affairs"' (Hurr Amili 1989: XXV/436).

\section{The Far Distances of the Mosque Restrooms}

In order to both preserve the purity of the mosque and prevent bad smells, religious leaders recommend us to build restrooms at the farthest area. Imam Musa al-Kazim quoted a narration, and he said: "Avoid the yards of mosques" (Kulayni 1987: III/16; Tusi 1987: I/30).

\section{Place of Ablutions in the Mosque}

If worshippers need to perform ablutions, the place of ablutions in the courtyard must be the closest place to the mosque. In a short period, they can get ready for prayers and other religious affairs.

In a narration from Prophet Muhammad we read: "Set up the ablutions place at the doors of your mosques" (Hurr Amili 1989: V/231).

\section{The Mosque Must Not Be Near Graves}

Muhammad ibn Abu Ya'qub Kulayni wrote in his Usul al-Kafi the reliable narrative quoted by Sema'a: "I asked Imam Jafar ibn Muhammad Sadiq about building mosques near graves, and then Imam answered: 'Mosques must not be built near agravesite"'(Kulayni 1987: III/228). Perhaps the reason for this ban was a specific issue that graves and the memory of their deceased could disturb worshippers from focusing on their prayers.

\section{Expansion of Mosque Building}

Because of the expansion of the Muslim population and the welfare of worshippers in a wider context, more teenagers' tendency to visit mosques, 
performing of religious or social ceremonies, we must expand the mosque's space. It is narrated in religious and historical texts that Prophet Muhammad came across a group of people working on the foundation of a mosque. (They were considering a small area for the mosque.) The prophet said: "Expand it (generally), and fill them". Due to the Prophet's command, they did (Khatib Baghdadi 1996: II/333; Jawadi Amuli 2014: 566).

We can examine the population and structure of a mosque in the rebuilding of the Mosque in Medina city. Because of the Muslim increasing population, the mosque was expanded several times.

\section{Public Places Turned into a Muslim Mosques}

Sheikh Hurr Amili wrote some narratives about mosque affairs in his book Wasail as-Shia. According to narrations by Isa ibn Qasim from Imam Sadiq, it was about Muslims who got the permission to destroy Christians' churches and Jews' synagogues, and then Muslims were allowed to rebuild them into mosques.

In the first hadith, which is quoted from Sheikh Tusis Tahzib al-Hakam, Isa ibn Qasim asked Imam Sadiq if they were allowed to pray in Christians' churches and Jews' synagogues. The Imam told him: "Yes". Then, he asked him: "Can we rebuild them as mosques?" Then, he told him: "Yes" (Tusi 1987: II/222).

In the second narration, quoted by Kulayni, Isa ibn Qasim said: "I asked Imam Sadiq: "Can we destroy Christians' churches and Jews' synagogues, and then rebuild them into mosques?" The Imam said: "Yes" (Kulayni 1987: III/368).

The Imam's opinions were important to social thinkers, because they wanted to make sure whether they should rebuild those constructions into mosques; and these places had to have Islamic theme.

Techniques and skills used in them set a pattern for building other mosques. In this case, strength, beauty and simplicity became the principles for building mosques. They replaced non-Islamic characters with flowers, plants, and verses from the Quran. They started the rebuilding by fixing the correct method of the modeling temples in accordance with Islamic principles.

Muslims were able to reform the standards of architecture of other nations into Islamic standards due to their spiritual and intellectual support. Some of the elements, such as the dome, minaret and the crescent structures, became the symbol of Islamic architecture (Muharrami 2011:276).

To sum up, we can talk about the following features of mosques:

1. The mosque is the architectural structure of Muslims and plays a key role in Islamic civilization. 
2. Simplicity of the mosque along with beautiful Islamic architecture has always provided a good situation to attract a wide range of people to monotheism.

3. The adaptation of art and religion, and one of its branches is architecture. Islam pays attention to this innate human desire, because God is the greatest artist in the universe. Zarrinkoub wrote about it: "Religion is not incompatible with art. On the contrary, they meet each other in the mosque. God is not only merciful and generous, but also beautiful, and He loves beauty. If we look at some of ancient mosques, they show that majestic buildings have been donated to God. Regardless of sacredness and spiritual joy, historians believe that these works are deemed to be Islamic art galleries" (Zarrinkoub 1983: 144).

\section{B) Recommendations of Religious Leaders in Islamic Architecture}

\section{Urban Planning}

Urbanization is the starting point and the beginning of civilizations. Advances, innovations, creativity and the creation of governments, all appear in urbanization. We must respect the principles of urbanization and Islamic architecture, and religious leaders have emphasized these principles.

\section{1. The City of the Prophet; the First Pattern of the Islamic City}

The most prominent historical emphasis on the urbanity of Islam is the Prophet's implementation in the first year of emigration. He implemented a comprehensive plan in Yathrib (Medina) city. He arranged the relations between the residents of the capital. These relationships include Muslim Immigrants, Ansar, and Jews by issuing a governmental constitution. He designed and implemented the civilization of the city.

First, he emphasized that pious Muslims in Yathrib (city) could form a united society, and therefore he taught them to respect their unity and their citizenship. Then, the Prophet established public institutions such as the Grand Mosque and the Saqifahs (a kind of building). Then he planned a map to make people live in several neighborhoods. He let each tribe in different local areas share their lands fairly and freely.

Moreover, the prophet recommended them to dedicate many areas to gathering people to hold their prayers such as Aid prayers (Hamidullah 1987: 45). 
The prophetic development programs in Yathrib include the following items.

The construction of Muslims' stores near Judaists' stores, respecting laws to supervise stores, cleaning the town through a suitable program, planning to make paths and alleys, building big houses with water closets (toilets), and making several chambers with private entrances to each house (Makki 2003: 99).

To provide water, the Prophet dug out a well and he dedicated it to Muslims. In the field of health services, he put up some tents at "al-Nabi" Mosque, which provided remedies for patients' health problems. The Prophet chose a place to slaughter sheep, and it was far from crowded places (Ibid.: 100).

\subsection{Building Formation}

Due to Islam's principles, there has been no certain uniformity for buildings for different places and time. The buildings have been built based on the conditions of time, place and fulfillment of desired goals in Islam. Hence, the Prophet said: "In terms of location and beauty, your cities should be prestigious, and they should have landscapes" (Suyuti 1981: I/13; Muttaqi Hindi 1989: 270). Religious leaders (Imams) have always advised on the development of cities. Amir al-Mu'minin Ali ibn Abi Talib wrote a letter and sent it to Harith Hamedani. He wrote: "Reside in big cities, because it is the Muslims' community center" (Sayyid Radiyy 2003: 69). The urbanization of Muslims also has affected the architecture of cities, and it would make cities have an Islamic theme. Particularly, Muslims were the conquerors, and they were the rulers of the highest religion (see: Muharrami 2011: 273).

\section{Making Green Spaces and Planting Trees in Urbanization, and Islamic Architecture}

There has been a relation between Islamic civilization and green spaces. Planting trees to flourish and refine cities, their purity and the attractiveness of cities are recommended in Islam. This matter was also considered by infallible Imams and the Quran. The Prophet said: "The reward of seven things is given to man even after his death: [...], and if he makes a brook, digs a well, plants a palm tree, and builds a mosque, the (spiritual) reward is given to him" (Karajaki 2015: 59).

Planting trees is very important in Islamic thought and architecture, and about this the Prophet said: "If you have a seed in your hand, and if you are very close to the Day of Judgment, don't hesitate and plant it" (Jawadi Amuli 2014: 710). He also said: "God damn the one who cuts the cedar tree" (Ibid.). 
As the Prophet was seeing off the Islamic troop, they were moving to Mutah (an area), and said: "Don't cut down any trees and don't wreck any houses” (Ibid.: 720). Specifying certain distances from Medina, the Prophet prevented people from cutting down trees.

\section{Houses facing the Qibla}

This issue has been emphasized in Islamic architecture. It could be important in some cases. First, people's unity with the only God, and it shows Muslims' houses should be a place for worshipping God and spiritual perfectionism. Islamic architecture is a divine-oriented architecture, and all Muslims' responsibilities must be divine.

God Almighty said it in the Quran: "Build your houses facing the Qibla!" (Quran 10: 87).

Another benefit of the houses facing the Qibla is that the whole city becomes united, and it converts it into a massive proportion having a beautiful, booming and magnificent theme. It also prevents the occurrence of false religious affairs, such as the burial of a dead person not facing the Qibla, the determination of the water closets location on building maps. They are very important issues because they are involved with the Qibla (Allama Amili 2010: 44).

\section{Encouraging Horizontal Development of Houses}

The largeness of a house has many benefits. The most important ones include the following items: the comfort of the home residents, the development of the family relationships, a suitable room to see the relatives inside, and the possibility of making a green space in the yard, which can bring happiness for us. The Prophet said: "It is a big happiness for a man to have a large house" (Barqi 1992: 610).

Ali ibn Abi Talib said about this: "There is an honor for everything, and the honor of the house is its bigness. There is a blessing for each house and the blessing of a house is to have a good place, a big courtyard and good neighbors" (Tabarsi 2002: I/249). Imam Jafar ibn Muhammd as-Sadiq said: "The largeness of the house can make a Muslim feel comfortable" (Barqi 1992: 611). The Prophet and his wife Khadijah had a beautiful house with four rooms. There were three indoor rooms. One room was for their children, and there was a room for the Prophet and Khadijah. There was another indoor room for them to say their prayers. It had a beautiful design, but free from any kind of worldly ornaments and decorations. It was very innovative and interesting. 
According to the examples quoted about the horizontal largeness of the houses, there are some other statements in the narrative texts by religious leaders (Imams). They banned the development of high-rise buildings; they believe that it is unacceptable (in Islam). Ahmed ibn Muhammad ibn Khalid Barqi mentioned an example of these traditions in his valuable book al-Mahasin. In a valid statement of this book, Imām Sadiq said: "Indeed, God has appointed an angel to the house, and if an owner builds the house roof much higher than four meters, the angel will say: 'Hey You! The evil man! Where do you intend to go?"' (Ibid.: 613). He said: "If the roof goes more than four meters high, it will be the place for the devils (Jinns)" (Ibid.).

\section{Avoiding Forbidden Manifestations in Architecture}

In Islamic laws, it is forbidden to paint images of animals or make their statues. According to some Islamic thinkers, making statues and painting of animals are prohibited jobs. In his book Al-Makasib, Murtaza Ansari said that sculpture is regarded as a social issue, and some famous scholars respected animal paintings (Ansari 1994: I/186).

Decorating houses and sculptures is also written about in Barqi's book al-Mahasin. In this book, we read that Imam Sadiq said: "Do not build houses on gravesites and do not paint pictures on the roofs, because the Prophet disapproved of them, and he was against them. Archangel Gabriel told the Prophet:'O Muhammad! Your Lord salutes you, and God prevents you from decorating houses"'. Abu Said asked Imam Sadiq: "What decoration?" He answered: “The images of statues" (Barqi 1992: 616; Kulayni 1987: VI/ 526).

There is another narrative reported by the Prophet. He said that Gabriel came to him and said: "Angels do not enter a house where there is a dog, an image of man and a statue" (Ibid.: VI/527).

Yes, there is a verse in the Quran saying: „Everything that Solomon wanted his men to paint on altar, they did" (Quran 34: 13). But, about this verse Imam Sadiq said: „I swear to God that those pictures were not images of men and women, they were images of trees and plants" (Kulayni 1987: VI/528).

\section{Breaking Images, and Removing them from Public Places}

One of the things that religious leaders used to care about was to eliminate innovations from the Islamic community. The result has also had a profound effect on the culture, civilization and architecture of Muslims. Some of these innovations were images and sculptures in Muslims' community, and some graves built with height. Today, we can see these problematic cases in Islamic countries again. 
Amir al-Mu'minin Ali ibn Abi Talib said: “The Prophet sent me to Medina, and he asked me to remove all images and even destroy high graves" (Ibid.). He also said: "The Prophet sent me to Medina to destroy the graves and break the sculptures"(Ibid.: 532).

\section{Building a Prayer Room inside the House}

One of the things that have been emphasized in Islam is a separate place or room to say prayers. In the analysis of this issue, some points cross our minds. It makes a human pay attention to the prayer and it can make spiritual inner feeling stronger. A clean and pure place in the house to worship God can teach the pious believer to have a house with a divine theme, and he should not forget the name of God in all aspects of his life. Having a prayer house at home can encourage children to pray, it can be very effective in their religious and moral education, and furthermore, it can make the pious believer spiritually calm. Imam Sadiq said that Ali ibn Abi Talib had a room that contained nothing but bedding, sword and the Quran. He said his prayers there. In another authentic narrative, also Imam Sadiq said: "I love to set up one of my rooms for prayer" (Ibid.: 538).

\section{Imams' Practical Methods and Practices in the Development of Islamic Architecture}

According to the famous narrative, the Prophet said: "Islam is against disadvantages and damages" (Saduq 1994: III/103). Some people hurt others in the community either because of their selfishness or ignorance.

They also destroy the structure of urbanization by their undesirable performance. They damage the principles of architecture and urbanization as well. Based on Islamic laws derived from the Holy Quran, the Prophet and Imams deal with such social anomalies. Islam teaches people how to live and have a healthy urban life by presenting practical solutions from the religious leaders.

Here are some ways to find out solutions:

\section{Removing Wastewater Wells and Pedestrians'Bothering}

Amir al-Mu'minin Ali ibn Abi Talib told the judiciary in the tribe of Saqif: "The water from the gutters which leads to the streets should be removed; take away all the wastewater wells which are on the way, these wells are in the way of Muslims and they bother Muslims" (Rawandi 1989: I/231). 
Such a strategy was very effective to protect the environment and health of the community. In addition, Imam Sadiq narrated that the Prophet said: "If a person makes the following mistakes, he must take the responsibility. For instances, if anyone puts the drains or sewage of his house on a passageway, knocks down a nail on the passageway, ties an animal somewhere, digs out a well and somebody crashes and dies, that person must take the responsibility" (Kulayni 1987: VII/350; Saduq 1994: IV/154).

\section{Destruction of Sitting Places}

Sitting places, where hooligans spend time and people commute a lot, can cause some problems.

A quote from an authentic narrative says that Amir al-Mu'minin Ali ibn Abi Talib was moving towards the Euphrates when he encountered Saqif, and some young hooligans ridiculed him. Imam said to them confidently: "Woe to you, you are the remnants of Samud and arrogant men. You are nothing but thugs. We are not in the same". The old men of the tribe said: "These are ignorant youths. Please, forgive us!" He said: "I forgive you on condition that when I come back again, you will have destroyed this sitting place. Take out the gutters leading into the street, and destroy the wells that are on the passageways. These are all in the way of Muslims and they are harassing them". They said: "We will obey all your commands". He went away, and they carried out the orders (Rawandi 1989: 89).

Abū Basir also quoted a long narrative by Imam Muhammad Baqir: "When Imam Mahdi al-Qa'im rebels, he will go to Kufa and destroy four mosques there; there will be no more mosques with battlements on earth. The Imam will destroy and eradicate all such mosques. Roads will be expanded, balconies overlooking alleys will be ruined. Front arches of houses and gutters leading to the alleys will be removed. In addition, he will remove all innovations, and he will set all traditions up" (Ibid.: 92).

\section{Destruction of Unauthorized Shops}

It is narrated that when Amir al-Muminin Ali ibn Abi Talib saw that there were some unauthorized shops in the street, he ordered his men to destroy them.

He was passing along to the houses of Beni Balqā, and then he said: "These houses were built near Muslim markets" (Allama Amili 2010: 143). Then he ordered his men to have them go away and after that, his men destroyed them. 


\section{Conditions of Sitting on the Ways}

Sitting down on the way where people pass along is impolite. Jahid writes in this regard: "Ali ibn Abi Talib in Kufa forbade people from sitting down on the way. He said:'I will allow you but there is a bet'. They said: 'O Amir, what is your bet?' Ali said: 'Close your eyes, respond to the greetings and guide those who have lost their way"' (Ibid.: 145).

\section{Conclusion}

This study shows that the Prophet and religious leaders (Imams) played a very important role in the strategic plans of Islamic architecture. We can find the starting point of this social movement in the construction of mosques by Imams.

The important issues of this fundamental movement at the beginning of Islamic architecture are some principles such as the principle of centrality, the principle of simplicity and avoidance of any luxury.

Religious leaders have also made recommendations in order to strengthen Islamic architecture that leads to a civilized society such as urbanism, creating a green space, houses facing the Qibla, encouraging horizontality of houses, avoiding prohibited manifestations in architecture such as construction of sculptures.

Another important point about religious leaders' advice are practical instructions and the development of architecture. They can bring about the harmonization of Islamic architecture. These recommendations could not only create the foundation of the construction and lawfulness throughout the city but also respect the rights of citizens in urban environments. Moreover, they also prevent the destruction of cities and the environment. They can also protect architecture from esoteric religion, illogical, luxurious, self-perpetuating, and harassing citizens. In this way, Islamic civilization will be promoted.

Received: September $23^{\text {rd }}, 2019$.

Accepted: November $20^{\text {th }}, 2019$.

\section{References}

The Holy Quran.

Allama Amili, Sayyid Ja'far Murtaza (2010), Shahre Islami: Neshaneha wa Shenaseha, Qom, Bustane Ketab. 
Amili, Muhammad ibn Ahmad (1998), al-Durus al-Shar'iyya fi al-Fiqh al-Imamiyya, Qom, Muassasa Al al-Bayt.

Ansari, Murtaza (1994), al-Makasib, Qom, World Congress on the Remembrance of the Sheikh Ansari.

Barqi, Ahmad ibn Muhammad ibn Khalid (1992), al-Mahasin, edited by Jalal alDin Muhaddith, Qom, Dar al-kitab al-islami.

Fattal Nishaburi, Muhammad ibn Hasan (1996), Rawdat al-Waizin, Qom, Radiyy Publications.

Fayz Kashani, Muhsin (n. d.), Mahajjat al-Bajda, edited by Ali Akbar Ghaffari, Qom, Entesharate eslami.

Hamidullah, Muhammad (1987), Awwalin Qanune Asasiye Maktub dar Jahan, Tehran, Bistat.

Hurr Amili, Muhammad ibn Hasan (1989), Wasail al-Shia, Qom, Muassasa Al al-Bayt.

Ibn Juzi, Abul-Fadail Abdur-Rahman ibn Ali (1992), al-Muntazam fi Tarih al-Muluk wa al-Umam, edited by Muhammad Abdul-Qadir Ata; Beirut, Dar al-kutub al-ilmiyya.

Ibn Majah, Abu Abdullah Muhammad ibn Yazid Qaywini (n. d.), Sunan Ibn Majah, edited by Fuad Abdul-Baqi, Beirut, Dar al-fikr.

Ibn Hisham, Abdul-Malik (1991), Siratu Ibn Hisham, edited by Mustafa al-Sakka, Ibrahim al-Abiary and Abdul-Hafiz Shalaby, Beirut, Dar al-ma'rifa.

Jawadi Amuli, Abdullah (2014), Mafatih al-Hayat, Qom, Isra Publication.

Jubai Amili, Zayn ad-Din (n. d.), Raud al-Jinan fi Sharhi Irshad al-Azhan, Qom, Muassasa Al al-Bayt.

Karajaki, Muhammad ibn Ali (2015), Ma'dan al-Jawahir, edited by Sayyid Ahmad Huseini, Qom, Entesharate eslami.

Karaki, Ali ibn Husein (1993), Jami al-Maqasid, Qom, Muassasa Al al-Bayt.

Khatib Baghdadi, Abu Bakr Ahmad ibn Ali (1996), The History of Baghdad, edited by Mustafa Abdul-Qadir Atta, Beirut, Dar al-kutub al-ilmiyya.

Kulayni, Muhammad ibn Ya'qub (1987), Usul al-Kafi, edited by Ali Akbar Gaffari, Tehran, Islamic Books.

Makki, Muhammad Kazim (2003), Islamic Civilization in the Age of Abbasids, translated by Muhammad Sepehri, Tehran, Amir Kabir.

Masoudi, Abu Ali Hasan ibn Husein (1989), Muruj az-Zahab, edited by Asad Dagher, Qom, Daru Ihya at-turath.

Miqrizi, Taqi al-Din Ahmad ibn Ali (1999), Amtia al-Asma', edited by Muhammad Abdul-Hamid Namisi, Bierut, Dar al-kutub al-ilmiyya. 
Muharrami, Ghulam Hasan (2011), The Role of Shiite Imams in the Formation and Development of Islamic Civilization, Qom, Imam Khomeini Educational and Research Institute.

Muttaqi Hindi, Alauddin (1989), Kanz al-'Ummal fi Sunan al-Aqwal wa al-Af'al, edited by Bakri Hayani, Beirut, Dar al-ma’arif.

Najafi, Muhammad Hasan (n. d.), Jawahir al-Kalam fi Sharhi Sharayi al-Islam, Beirut, Daru ihya at-turath al-arabi.

Naqizadeh, Muhammad (2008), Islamic City and Architecture, Isfahan, Mani Publishing.

Nuri, Husain bin Muhammad Taqi (1988), Mustadrak al-Wasail, Qom, Muassasa Al al-Bayt.

Priest, Christian (1985), The History of Islamic Art, translated by Masud Rajabniya, Tehran, Elmi wa farhangi.

Rawandi, Qutbuddin (1989), al-Kharaij wa al-Jaraih, Qom, Muassasa Imam Mahdi.

Saduq, Muhammad ibn Ali ibn Babiwayh (1994), Man La Yahzuruh al-Faqih, edited by Ali Akbar Ghaffari, Qom, al-Intisharat al-islamiyya.

Saduq, Muhammad ibn Ali ibn Babiwayh (2006), Ilal al-Sharai', Qom, Dawari.

Sayyid Radiy, Abul-Hasan Muhammad ibn Husein (2003), Nahj al-Balagha, translated by Husein Ansariyan, Qom, Dar al-irfan.

Suyuti, Jalaluddin (1981), al-Jami al-Saghir, Beirut, Dar al-fikr.

Tabarsi, Abu Ali Fazl ibn Hsan (2002), Makarim al-Akhlaq, translated by Ibrahim Mir Bakri, Tehran, Elmi wa farhangi.

Tusi, Muhammad ibn Hasan (1987), Tahzib al-Ahkam, edited by Hasan Musavi, Tehran, Islamic Books.

Tusi, Muhammad ibn Hasan (2008), al-Mabsut fi Fiqh al-Imamiyya, Tehran, Islamic Books.

Yaqubi, Ahmad ibn Abi Yaqub (n. d.), Tarikhu Yaqubi, Beirut, Daru Sadir.

Zarrinkoub, Abdul-Husein (1983), Karnameye Eslam, Tehran, Amir Kabir Publications. 